\title{
新たなクリニカルリサーチの展開を目指して
}

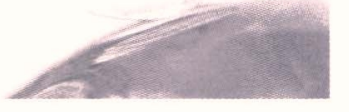

\section{歯科臨床における東洋医学 末来への遺産}

市村 葉，横瀬敏志，門倉弘志，田島直人，柿坪秀具，片山伊九右衛門，片山 直

\section{要旨}

医療現場において，アレルギーや全身疾患などによ り，薬剤や診療器具の使用が難しい患者や，原因不明 の痛みや麻痺を伴い, 今までの西洋医学的療法の限界 を感じる場面が増えてきている。このような背景から， 代替医療に注目が集まり，なかでも見直されているも のに東洋医学があげられる。今後，歯科領域の分野で も東洋医学的知識は欠かせないものとなると予測され る。しかし，実際の医療現場においては，まだまだ末 開の療法，末知なる原理によるもの，さらには奇怪な 現象と考えられている部分も多く, 治療法の第一選択 となることは少ない。そこで本稿では，歯科臨床にお ける鍼療法の応用と現象を検証し，その有効性につい て概説する。

はじめに

東洋医学とは何か, と一言で説明するのは難しい. もともとは，中国古来より自然とともに育まれてきた 様々な現象と人体との関係を根底にした中医学であ り，それを日本の風土および日本人の体質に依拠しな がら発展してきたものである。

すなわち，東洋医学とは中医学そのものというより も，それに日本独自のものを加味したものといえるか もしれない。いわゆる西洋医学との大きな違いは，人

明海大学㐘学部保存修復学講座
体を一つの大きな有機体としてとらえていることで, 一つひとつの組織が独立した存在ではなく，互いに連 絡をとりあいながら，人体を構成していると考えるこ とである。たとえば，内臓をみてみると，五臓（肝， 心, 脾, 肺, 腎) と, 六腑 (胃, 小腸, 大腸, 膀胱, 胆，三焦）とに分けられる。それぞれ固有の特徴をも ちつつ, 互いに協力しあいながら, 経絡や臓, 腑, 体 表などを往来し，それぞれの働きに協力すると考えら

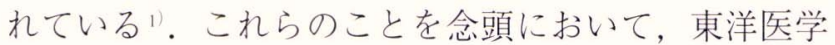
的診断を行い, 治療を行っていくのである. 治療法の なかに，ツボ，経絡の刺激というものがある。その手 段として，銊，尒，あんまなどがある。

本稿では，鍼によるツボ刺激において，その効果と 有効性, さらに $\mathrm{CO}_{2}$ レーザーを応用した場合にもふれ， 歯科臨床に拀ける将来性について, 日ごろ行っている 臨床例と併せて考察する。

\section{東洋医学的診断とは}

\section{1. 証}

証とは，疾病の位置や性質，原因などを総合的に表 したもので, 疾病の本質にあたり, 単なる症候群を指 すものではない。

\section{2. 弁証論治}

并証とは，患者から情報を収集し，得られた情報を 
分析することである．証を決めるために必要な方法と しては，四診という4つの診察方法を用いる，次に， 四診で集めた情報を分析するために，いくつかの弁証 方法がある。それらの情報から証を導き出す，論治と は，証に従って治療方針を立てることである”。

上記の過程を経て初めて治療に入るのである，実際 の治療では, 銊, 炎, あんま, 漢方薬の処方などがある.

\section{1）四診}

\section{（1）問 診}

主訴, 既往歴, 現病歴などを患者に問うことで情報 収集する。

\section{(2) 望 診}

全身や局所の状態, 舌の状態をみることで情報収集 する．舌の状態をみることを特に舌診という.

(3) 聞 診

患者の音声を聞いたり，排泄物の臭いを嗅いだりし て情報収集する。

\section{（4）切 診}

身体に触れたり，脈を取ることで情報収集する。

\section{2）弁 証}

四診で得た情報を分析し，証を決定する．

\section{3）論 治}

決定した証から治療方針を立てること．この治療方 針を治法という。

\section{4）治 療}

実際の治療では，鍼，炎，湯液，あんまなどがある. いずれも治法に従い行われる。

\section{経絡,ツボ}

経絡とは，人体を絶え間なく流れる気，血がめぐる 通路である，臟腑と器官，体表などをつなぐ連絡網で ある，経絡上にはツボ (経穴) があり, 診断, 治療に 不可欠なものとなっている. ツボは, 人体に 360 以上

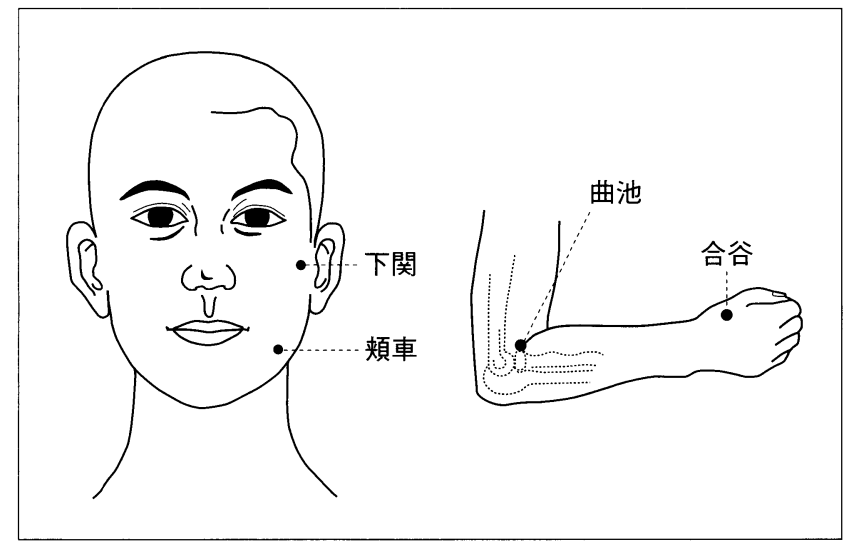

図 1 頡関節症のツボ2)

あるといわれ，気血の集まるところである，そのため， 気血の不調はツボの反応となって現れる，気血の不調 とは，疾病であったり，過敏反応であったり，体調の バランスが崩れることをいう。

鍼，尒などの治療は，このツボを刺激することで， 気血の流れを調整し，疾病を治癒するものである.ツ ボにはそれぞれ特有の働きがある。

\section{銊 療 法}

歯科臨床でしばしば遭遇する疾患において, 鍼療法 を応用しやすいものを下記にあげた。

\section{1. 䫟関節症への応用}

顎関節における痛みを伴う症状や, 周囲筋肉のこわ ばりなどの症状がみられる患者には, 図1に示すツボ に置針する。

\section{2. 顔面神経麻痷への応用}

発症から早期の銊治療によって回復を早めるが, 治 療開始が遅れると回復も遅れる傾向にある。銊治療は 顔面麻瘏側の筋力の萎縮を防ぎ, 目, 口の運動が軽快 になる.これらの効果を期待して, 図2に示すツボに 置針する。

\section{3. 三叉神経痛への応用}

三叉神経痛の銊療法は，疼痛部を走っている経路を 


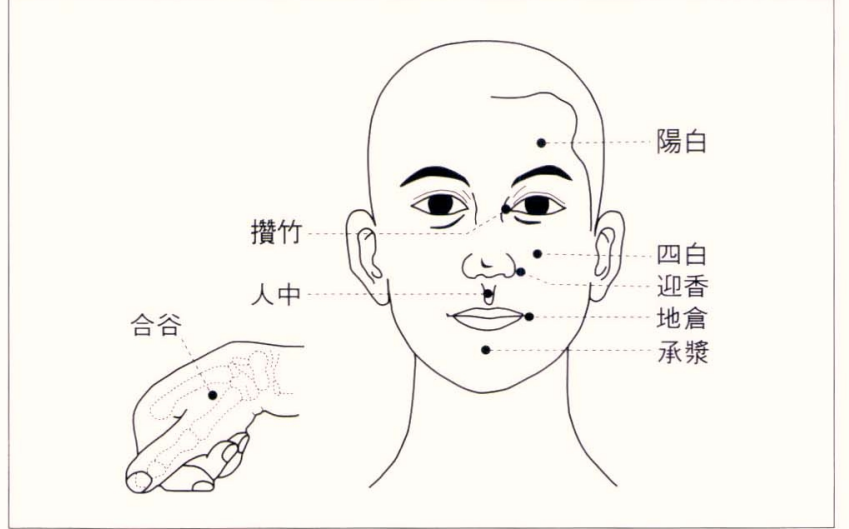

図2 顔面神経麻痺のツボ 2

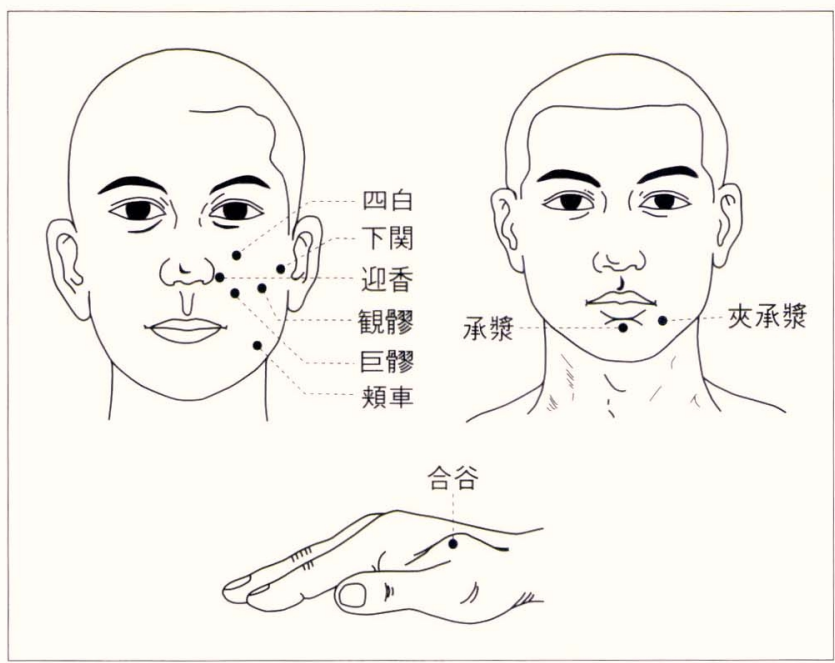

図３三叉神経痛のツボ2

たどって，その四肢部のツボを選び，局部には圧痛の ある点を探して刺す，合谷を一極とし，一方の極は特 に痛みのある部位に求める。三叉神経痛に応用される ツボを図ろに示した。

\section{$\mathrm{CO}_{2}$ レーザーのツボへの応用}

以上，鍼の効果を述べてきたが，鍼自体に恐怖心を 覚える患者や，感染の問題など，鍼の使用にあたって は様々な危険も考慮しなければならない。

また，正確なツボへの鍼刺入には熟練を要すること も事実である。そこでわれわれは，鍼使用におけるこ れらの危険性のない，簡易的な銊様療法として， $\mathrm{CO}_{2}$ レーザーの応用を試みている。使用している $\mathrm{CO}_{2} レ$
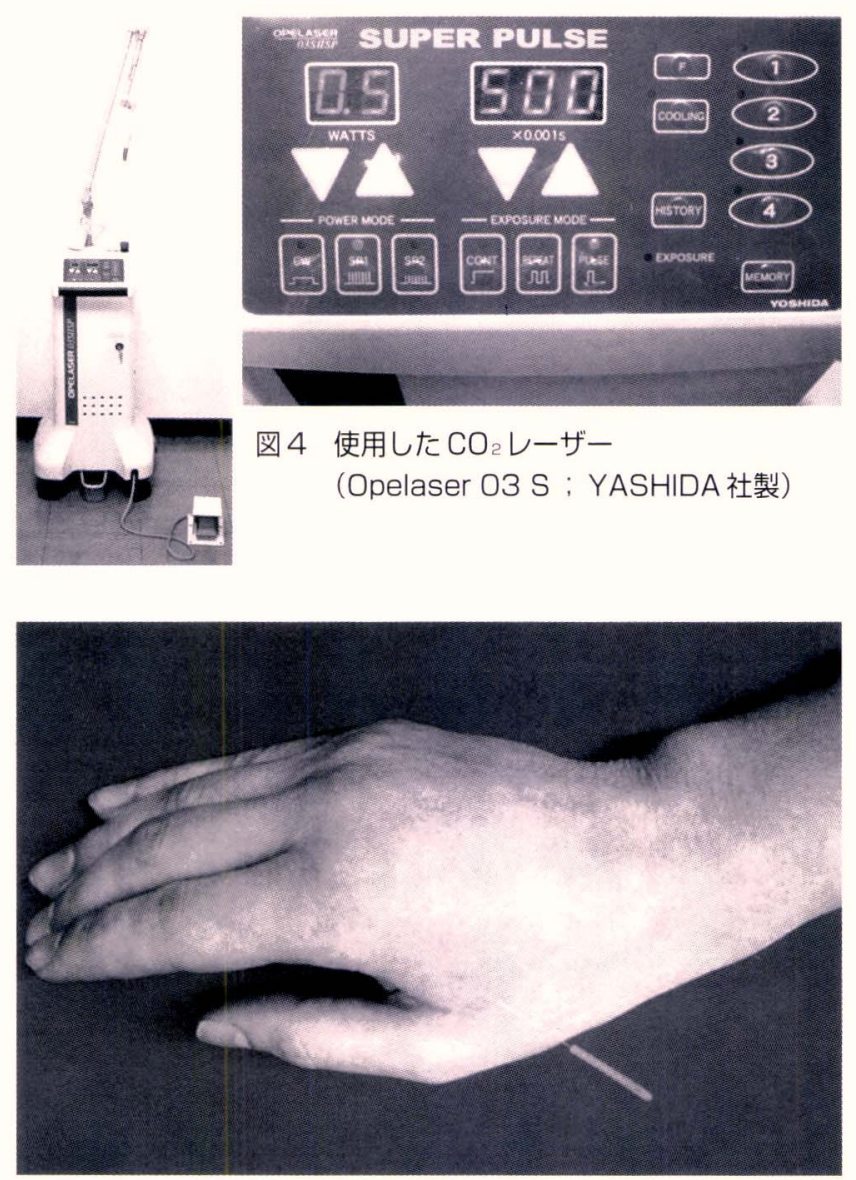

図 5 合谷への置針

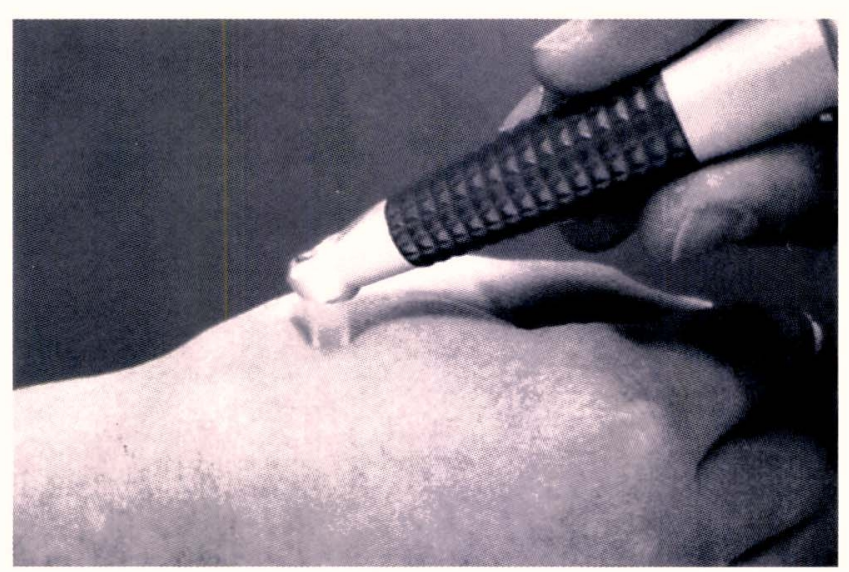

図6 合谷への $\mathrm{CO}_{2} レ$ レ゙ー照射

ザーを図4に示す.

$\mathrm{CO}_{2}$ レーザーの特異的な組織深達性 ${ }^{3}$ に着目し, ツ ボへの $\mathrm{CO}_{2}$ レーザー照射によって, 銊と同様の刺激が 得られるか検討を行っている. その中のいくつかの治 験から, 合谷への $\mathrm{CO}_{2}$ レーザー照射によって(図 5, 6), 


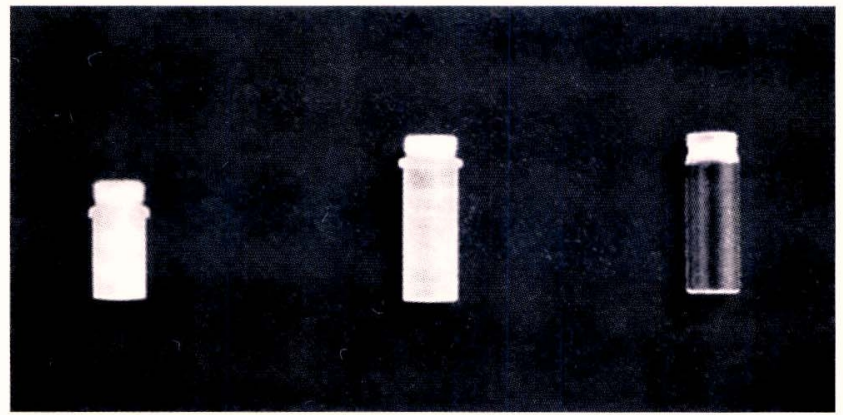

図 7 試作チップ

鍼と同様の部位の温度上昇が確認された。今後, より

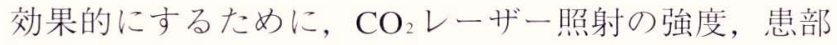
からの距離, 照射時間の検討を行うことが課題である。 現在いくつかのチップを試作し（図7,8), 治験を 行っている.

\section{おわりに}

東洋医学においては, 疾病を単なる局所的症状とと らえるのではなく, 東洋医学的に全身状態の一症状と 考えることで，八リ療法の有効性が発揮されている。 たとえば，顎関節症における痛みの緩和や除去，顔面 神経麻瘒, 三叉神経痛における痛みや麻痺の除去, 術 後の痺れや神経症状の改善, アレルギーなどにより麻 酔薬や薬物投与の難しい患者への応用も報告されてい る ${ }^{4}$.このように，歯科領域にとどまらず，東洋医学 の有効性は再認識されつつあり, そのメカニズムなど

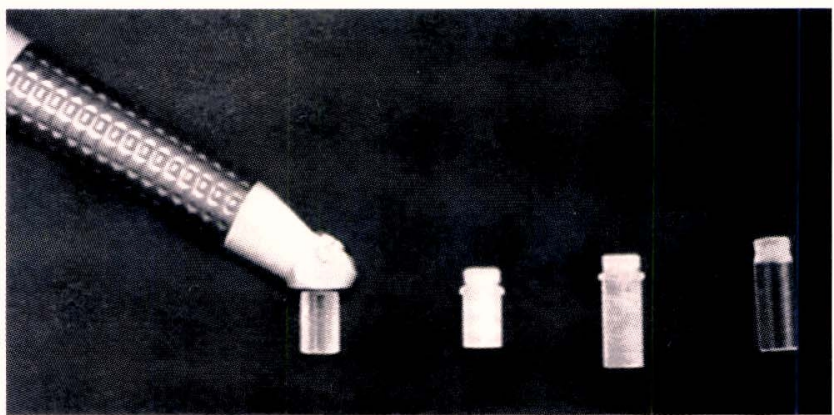

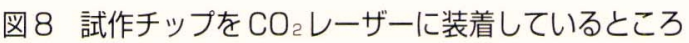

について急速に研究されてきている。重要なことは, 東洋医学の安易な導人ではなく, 西洋医学とは異なっ た認識からくる診断法や考え方をよく理解し，科学的 根拠への探求もしながら，4,000年の歴史に育まれた 遺産の有効性を発展させていくことである。今後, 東 洋医学は未知なるものから必須の存在になるであろう と確信する。

\section{参考文献}

1）邱 紅梅：わかる中医学入門. 燎原書店 (東京), 1999.

2) 片山伊九右衛門：歯科ハリ治療マニュアル。医歯薬出版 (東京), 1990.

3）横瀬敏志ほか：炭酸ガスレーザーの細胞生物学的作用と 細胞情報伝の関係について一MAPキナーゼの活性化と レーザーの作用。デンタルダイヤモンド, 27(16)：152153, 2002.

4) Yamamoto, T. : Yamamoto new scalp acupuncture. 175-183, メディカルトリビューン (東京), 1998. 